\title{
Wo[e]man in the Quest for Women's Identity: Myth and Symbolism in Angela Carter's The Passion of New Eve and Youssef Zeidan's Zil Al-Afa'a [The Shadow of the Serpent]
}

\section{Hala Zakariya Khalifa Ahmad}

\begin{abstract}
A public that tries to do without criticism, and asserts that it knows what it wants or likes, brutalizes the arts and loses its cultural memory [...]. The only way to forestall the work of criticism is through censorship, which has the same relation to criticism that lynching has to justice.
\end{abstract}

(Northrop Frye, Anatomy of Criticism, 1957)

Myth, or mythos in Greek is, and has always been, a never depleting mine for the world of belle-lettres and criticism since the times of the ancients down to our present. M.H. Abrams describes myth as a story that forms part of a mythology; that is, an entire system of stories that are passed down to posterity and "which were once believed to be true by a particular cultural group and which served to explain why the world is as it is and things happen as they do, [and] to provide a rationale for the rules by which people conduct their lives" (Abrams 1993, 122). As such, mythology, as Abrams declares, is like a religion in which no one believes any longer. This pseudo-religious aspect of myth can perhaps account for its ritualistic and ceremonial aspects.

Abrams differentiates between myth, legend and folktale, and identifies myth as part of a systematic mythology. If the hero of a story does not have supernatural status, the story is regarded as a legend; and if the story involves supernatural beings who are not deities and the story does not belong to a mythological system then we are clearly looking at a folktale $(1993,122)$. In its degraded, common and modern status, a myth has come to signify simply an untrue story.

In his Republic, Plato seems to endorse the opinion that myth is a falsehood, a fictionalized story that functions as an edifying or a protreptic tool whose purpose is to inculcate certain ideas in the course of training the children and

\footnotetext{
* Lecturer in the Department of English Language and Literature, Faculty of Arts, Cairo University.

Cairo Studies in English - 2021(1): https://cse.journals.ekb.eg/
} 
youth of the perfect state. He even went as far as to suggest that teachers or trainers of future guardians invent some myths to instill virtue and heroism in the youngsters (378a-380c). Yet, Plato, however, seems to have a very loose definition of both myth and legend, which may or may not be translation related. In his discussion of fictionalized narratives, for instance, Plato puts forward the following query: "May not all the compositions of poets or legend-writers be described as narrations of past, present, or future events?" (Rep. 392d). Then later, he speaks about using mythical language to convince the people in whom God had put gold, silver or iron and copper in His creation of them (Rep. 414a415a).

Roland Barthes seems to concur with Plato on the point that myth can be a contemporaneous invention. In his book Mythologies, Barthes identifies certain scenes or concepts taken from everyday life and ascribes a mythological status to them. For Barthes, myth is a "system of communication... a message" (Barthes 1957, 107). It is also a type of speech and part of the science of semiology, which he defines as a science of forms, concerned with signification not content. Besides regarding myth as a form, Barthes also assigns a historical basis to it. Whether they are classical or not, myths are also part of what he calls "historical science" (111); and myth, therefore, is partly ideological.

Because Barthes regards myth as part of a semiological or linguistic system, the raw materials of mythical speech, such as language, photography, sports, rituals or objects, boil down to mere language, becoming a sum total of signs or a global sign. For Barthes, the signifier in myth is a mental image which also has an appearance, a substance and a form and is at once empty and full because the signifier in myth is the sign in the linguistic system, making the signifier which is the sign in the linguistic schema both form and meaning as well. The signified, on the other hand, is the concept whereas the sign is that which associates the image with the concept or the signifier with the signified (111).

As Barthes points out, in examining myth, we are faced with a semiological or linguistic as well as a mythical system. In myth, the history of the sign which has become a signifier gives way and empties itself of its history in order to prepare itself for the signified. Keeping meaning at a distance, the signifier in myth becomes form, hiding inside the meaning of the myth, creating a kind of absence in presence or vice versa. On the other hand, history which is drained out of the mythical signifier, i.e., the form, will be absorbed by the signified or the concept (117). In myth, Barthes states that there can be numerous signifiers or forms to suggest the concept or the signified. Having the concept repeated through different forms or signifiers is important in deciphering a myth. The 
concept or the signified, being condensed, is therefore nebulous, which in turn distorts or alienates meaning (121).

Barthes (1957, 125-26) also adds that signification/meaning in myth is never arbitrary as the sign is in language; there is always some relational analogy supplied by history to the form, that is, the signifier which motivates both the form and the myth. However, the analogy between meaning and concept is never complete due to the quantitative poverty of the concept or the signified. Put differently, since forms or signifiers are motivated by the concept or signified which they represent albeit without covering all the possibilities of such a representation, mythical signification becomes arbitrary eventually. The partial image which results appears always in the form of caricature, pastiche or symbol.

The mythical signifier, furthermore, can be seen as consisting of both (linguistic) meaning and form, signification becomes ambiguous because the signified is no longer a symbol and assumes a clear presence. This ambivalence of seeing myth as a story that is true and untrue, says Barthes, is what moves the mythical schema from semiology to ideology. Barthes stresses the importance of the signifier in myth, regarding it as instrumental to conjuring up the concept and realizing signification or meaning. Also important is that myth essentially aims at making an "immediate impression" (127-29).

Northrop Frye was not less interested in the potency of myth in conveying meaning and states categorically that "the structural principles of literature are as closely related to mythology and comparative religion as those of painting are to geometry" (Frye 1957, 134-35). Notwithstanding Frye's argumentation for literary archetypes which may not have endured as a literary fad, the fact remains that myth, as an abstract and conventional literary mode, as he maintains, is a powerful vehicle for transcending the limitations of representative reality which is constrained by plausibility (136). In that context, Frye's polemic is that "mythical imagery is usually represented by the conception of heaven or paradise in religion, and it is apocalyptic [...] a world of total metaphor, in which everything is potentially identical with everything else" (136), or, as he says a few lines later, "as realism [being the art of verisimilitude] is an art of implicit simile, myth is an art of implicit metaphorical identity" (Frye 1957, 136). In this, he seems to agree with Barthes who defines myth as a type of speech and "a mode of signification" (Barthes 1957, 107).

Myth, then, with its overcharged symbolism and eschatological undertones, becomes the fitting trope par excellence for signifying the modern Man's condition and, more particularly, the modern woman's angst as she lives in a phallocentric world that is still endeavoring to marginalize her. Myth, as the 
paper aims to demonstrate, becomes the woman's trope that raises dust, as it were, in the face of a postmodern world, operating as an eye-opener or a bell making a late wake-up call. Myth without any further ado functions in the two works to be examined as a road sign for woman, a revival of her spirit and a resurrection of her past glory, even if Angela Carter, sadly and ironically, seems to hold a deprecatory view of the very weapon she had opted to wield by stating:

\begin{abstract}
All the mythic versions of women are consolatory nonsenses; and consolatory nonsense seems to me a fair definition of myth [...]. If a revival of the myths of these cults gives women emotional satisfaction, it does so at the price of obscuring the real conditions of life. This is why they were invented in the first place. (Carter 1978, 5)
\end{abstract}

Despite Carter's paltry view of myth, myth succeeds in revealing some of the sordid realities of life and without giving women a free ride to heaven so to speak. In her novel The Passion of New Eve, Evelyn/Eve is the hub of the novel's mythological schema and its pivotal sign that is literally set on a quest to reach a meaning for an elusive self whose reality is as tantalizing as an image reflected in a mirror in a world as puzzling as a maze. Evelyn/Eve is also the overarching mythical symbol of the novel whose questionable binary opposition transcends any sexual ambivalence. The Fall of Evelyn, if we are to make that assumption, comes to herald a new beginning (for Women?) and signal an ending that threatens to annul everything including Evelyn, the old sign and the new signifier in the mythical schema, and Eve, the motivated concept that seeks a new meaning for woman.

The aura of decadence and entropy is evident from the very first pages of the novel. There is a sense of imminent doom pervading Evelyn's new world right from the onset, a belief that "God had arrived on a celestial bicycle to proclaim the last Judgement was at hand" (Carter 2009, 8). We are also warned that "women are angry" (8); with the female circle inscribed everywhere and God riding on "luminous wheels," a symbolic sense of ending, of things coming full circle as it were is looming in the horizon, not to mention that the circle is also a symbol of perfection and ambivalence, of enclosure and disclosure. It is a tomb and a womb both at once.

Evelyn needed his forbidden fruit, the temptation that must precipitate his fall, a fall that is necessary for a new beginning. Leilah was that New York "apple", so to speak, in the flesh and Evelyn was only too eager for that Fall; or in his 
own words: "I felt all the ghastly attraction of the fall.... I took the quickest way down, I plunged" (21). The question one is faced with is: did Evelyn's sin have anything to do with his pursuit of Leilah who had played the roles of both quarry and hunter to the bird of prey? (21) or did his so-called sin that necessitated the so-called Fall, literalized in his descent into Beulah, have more than meets the eye? Evelyn could only see the succubus side of Leilah who comes to tempt the saints (23). Aligning Leilah with the devils and himself with the saints only shows his lack of knowledge of the fruit he had partaken of, together with an ignorance that he has entered where the gods dwell as well, as the Latin legend written on Leilah's entrance wall signifies. Strikingly, the same Latin tag is inscribed on the pediment of the broken phallus in Beulah.

In fact, one of the signifiers of the novel is Leilah whose name conjures up the night, mystery and the allurement of the East. Leilah is a signifier but is also a quondam sign - in Barthes's configuration - for passive femininity and the facetious innocence of the oriental concubine. She reeks of musk and submissively lies chained to her bed during the day to display her naked body in New York's night venues at night. The long history of her kind is embedded in her name - a name that has to be emptied of its history to usher in the mythical signified, Lilith, who, as it turns out, is her real name, carrying with it all the mythical significance of the name. Leilah can only reveal her mythical name which is her real name and also reveal her true identity towards the end of the novel when she becomes one of the city militia of Los Angeles, again making her ambivalence more tenebrous by identifying herself with Adam's demon wife who rebels against the role of female submissiveness in a city whose very name professes to be a city of angels.

Whether Leilah is an angel as suggested by her virgin (-like?) innocence or a "fallen" angel, Evelyn's sin against her has made him guilty of sinning against all women. He had not only abandoned her and forced her to have an abortion but had made her sterile. Leila's womb will never bear any children. Evelyn was unable to take all this in or as he recounts:

The sickness of the ghetto and the slow delicious sickness of femininity, its passivity, its narcissism, have infected me because of her. She has been doubly degraded, through her race and through her sex [...]. All these absurd notions flickered through my injustice as I tore hell-for-leather through the night. (Carter 2009, 29, 33) 
But Leilah, in fact, had been thrice wronged. If she may have been wronged and driven to the fringes of society by her race and sex, Evelyn had done her the illservice of killing all her posterity. Justice had to be done; and it had to be effected by Leilah's mother who, in Evelyn's faulty white, bourgeoisie, male, chauvinist logic, he had thought her to be a scrub woman. Leilah's mother, as it turns out, is not only myth in the flesh but seems to be even beyond history, embodying both the signifier and signified or as she herself puts it: "I am the wound that does not heal. I am the source of all desire. I am the fountain of the water of life [...]. Life and myth are one!" (61).

In Beulah, the subterranean womb in the heart of the California desert (with its super charged Biblical significance), Evelyn becomes Eve at the hands of the mother who will try (but fail) to impregnate him with his own semen. Inside that "simulacrum of the womb" (47) where "Mother has made symbolism a concrete fact" (55), Evelyn is reborn and given a new identity. He is emptied of history (or isn't he?) in order to enter the world of myth and symbolism of the Mother who will wreak her "mythic vengeance" (47) on him.

In her interesting article that offers a Jungian interpretation of Carter's text, Maria Perez-Gil dismisses the Mother's depiction as quite hilarious and even inviting mockery. She also maintains that "[t]his literal staging of psychoanalytic, biblical, and Greek myths makes the Mother's project appear nonsensical" (Perez-Gil 2007, 10). Let us not forget, however, that Mother in Carter's work is the living incarnate of all myths in all places and of all time. It is perhaps the overwhelming rhetoric of myth and blatant symbolism which makes the Mother the literalized larger than life deity who had made her own self and "was her own mythological artifact" (Carter 2009, 57) which is too much to grasp. The Mother in The Passion of New Eve dismantles or deconstructs the notion of god the Patriarch. The broken phallus at the entrance of Beulah is testimony to the Mother's thunderous pronouncement: "I am the Great parricide, I am the Castratrix of the Phallocentric Universe, I am Mama, Mama, Mama!" (64).

This self-proclaimed holy trinity is juxtaposed by the poet zero who blames Tristessa for his sterility, accusing her of casting a spell on him. And yet, he, too, had created his own myth, enslaving his seven wives by making them believe in the healing power of his semen. Thus, they dedicated themselves, we are told, to the Church of Zero. Not in any way less articulate than "Mama," though his misanthropy made him prefer to speak in grunts, Zero's authority was as indisputable as his self-aggrandizement. Evelyn describes her confinement at Zero's ranch - house thus: "The ranch-house was Solomon's Temple; the ghost 
town was the New Jerusalem; the helicopter his chariot of fire; his prick his bow of burning gold, etc, etc, etc" (97).

Because doubling is a feature in Carter's text, Zero assumes the role of god the Patriarch. His profligacy, sodomy, sadism and negativism are also heavily highlighted and give him a striking resemblance to the Marquis De Sade, the biography of whom is meticulously recounted by Ronald Hayman. If the Mother has her harem of "vestals", he too has his own "harem" of submissive wives. Mother had raped Evelyn and he raped Eve, but both were unable to impregnate $\mathrm{him} / \mathrm{her}$. Zero's ironic name echoes the symbol of the circle which functions as one of the many motifs in the novel. Being associated with the angry women's sign, Zero offers another example of Carter's subversive tongue-in-cheek technique of deconstructing her own myths and symbols. It is therefore apt that a place like Beulah is described as the place where "contrarieties exist together" (45). Eve(lyn) is also told that (s)he will bring to the world "the Messiah of the Antithesis" (64).

Likewise, Evelyn and Tristessa, as Rachel Carroll points out in her exploration of queer theory intent in the novel, are "in many ways doubled in the narrative, a strategy which culminates in their double wedding [...]. In the often mythical, alchemical images of the narrative, this doubling seems to promise a mythical reconciliation of opposites" (Carroll 2011, 3). After being raped twice, first as a man by Mother and then as a woman by Zero, Eve(lyn) is forced to consummate a mock-wedding with Tristessa, which heightens the novel's irony and stretches it to the limit. Eve(lyn) as Carroll signifies him/ her is "a postoperative male-to-female transsexual whereas Tristessa is a non-operative maleto-female transsexual passing as a woman" (Carroll 2011, 3). In both cases, the signifier does not seem to point to the assigned signified; the concept is always an ironic parody, a distorted image of the form, or the signifier. To explain further, Evelyn falls short of conceptualizing the Fallen Adam. Even when he becomes Eve, Zero, the ultimate nullifier, can only laugh at the name, at the new signifier, and jocularly retorts: "You Eve [...]. Me Adam" (Carter 2009, 88), which is another pointed finger at parodied doubling. In the course of the novel, he comes to look at her with sexual suspicion, wondering at her feminine perfection, as if he could see the cock Eve felt twitching inside her head.

That same member is what Tristessa has endeavoured to hide all her life. An amalgam of tryst and tristesse, "Our Lady of the Sorrows" (Carter 2009, 118) has been the sensuous fabrication of the mythology of the flea-pits" (125). No wonder Eve recognizes her/him as her/his double, as seems typical of the novel's characters who reflect and refract each other. Eve(lyn) sees himself reflected in 
Tristessa's eyes as he sees his childhood and adolescent idol before his eyes. Eve(lyn) reflected on her encounter with Tristessa thus: "The abyss on which her eyes open, ah! It is the abyss of myself, of emptiness, of inward void. I, she, we, are outside history; we are beings without a history; we are mysteriously twinned by our synthetic life" (122). In fact, history is not part of the equation here; the mythical schema fails.

The synthesized myth fails as the chosen trope for finding meaning to a world on the brink of opening the final chapter of revelation. To illustrate, Evelyn escapes the helix of Beulah, inside the womb of the barren desert, without bearing the fruit of Mother's painstaking surgery. Furthermore, Tristessa's glass castle of concentric circles, housing "the false goddess" (152) and her waxwork of Hollywood's celluloid myths, is shattered as well. Her "mausoleum," her "Temple" (109) collapsed in a devastating whirlwind that had also sent Zero and his harem of seven wives to be "gone with the wind" as it were. The magic circle of infinity is dismantled as this fake/artificial female space of a glass womb/tomb gets destroyed together with the empty/sterile phallocentricity of "Fatherless time" that Zero seems to represent. Myth, emptied of history, generates "parodied myth" (75). That is why Eve(lyn) describes his/her wedding to Tristessa as a venture into "the realm of negation" (132). She says in her retrospect narration:

You and I, who inhabited false shapes, who appeared to one another doubly masked, like an ultimate mystification [...]. Circumstances had forced us both out of the selves into which we had been born and now we were no longer human - the false universals of myth transformed us [...]. We were beings composed of echoes. (Carter 2009, 64)

When history does not fill the form; i.e., the signifier, myth is not motivated, as Barthes seems to indicate. In The Passion of New Eve, history and myth are engaged in an embattled tension in which they are not reconciled. Sophia tells Evelyn that "[m]yth is more instructive than history" as Mother is about to carry out her surgical transgender experiment. Then later in the novel when we learn that Mother had abdicated her mythical position as "god-head," we are told in Leilah or Lilith's own words that "[h]istory overtook myth" (65), and that "historicity rendered myth unnecessary" (169).

Eve had to go through history's portal so that her new signifier, the old sign, could designate the concept or the assigned signified. In other words, she had to 
be reborn, but this time by going through the womb-like watery cave by the ocean so as to realize "how glorious it is to be a woman" (178) and to come to terms with her history-laden myth and her new femininity. Inside the three-part cave, time regresses to its primordial essence while Eve encounters symbols from her past and gropes for her way out until she in expelled from the amniotic water of the cave, crying out like a newborn for her mother. In the same vein, Salomé Sola Morales draws attention to how myth is used as a means of explaining processes of transformation or transition and hence its liminal aspect. Functioning as part of the initiation process of individuals, myth thus works as a rite of passage (Morales 2013, 35-36). With historicity and myth finally reconciled (are they?) Eve emerges as the newly born millennial woman; the transformation is consummated with Leilah handing Eve(lyn) her genitals preserved in an ice box. Eve's laughter not only sends the box swimming but bids farewell to an old past that has diminished into a logos or a semiological sign .

In Carter's favoured realm of intertextuality, and recalling Plato once again as he expounds how myth is made for the purpose of training and instruction, he says:

[W]hen we were training and instructing them, they only fancied, as in dreams, that all this was happening to them and about them, while in reality they were in course of formation and training in the bowels of the earth [...] and from whence, as soon as they were thoroughly elaborated, the earth, their real mother, sent them up to its surface; and consequently, that they ought now to take thought for the land in which they dwell, as their mother and nurse. (Rep. 414d-414e)

Although Eve's learning experience is debatable, she gets ready to go back to the old world where she came from, leaving Lilith, her double, who has also had her rite of passage. Eve knew only too well that Leilah "could not abdicate from her mythology as easily as that" (Carter 2009, 175). She still had a new dance to perform. Her first was called the end of the world and her second might usher in a new beginning out of the chaos and the decadence that the spurious myth Tristessa and Zero had signified. Carter's novel, above and beyond everything, is a feminist work seeking an answer to what it means to be a man and what being a woman actually means. The Oedipus-like riddle remains controversial or unresolved and an easy way out of the intricate maze is not guaranteed. Eve or perhaps Carter herself summarizes this dilemma as follows: 
Masculine and feminine are correlatives which involve one another [...]. But what the nature of masculine and the nature of feminine might be, whether they involve male and female, if they have anything to do with Tristessa's so long neglected apparatus or my own factory fresh incision and engine turned breasts, that I do not know. Though I have been both man and woman, still I do not know the answer to these questions. Still they bewilder me [...]. I have not reached the end of the maze yet. I descend lower [...]. I must go further. (146)

Despite Carter's unanswered queries, her penchant for antithesis that overturn every binary opposition on its head only to somersault once again, her oeuvre almost says it all, so much so that reading Zeidan's (Zil Al-Afa'a) The Shadow of the Serpent (all the Arabic quotations are translated by the author of this paper) is reduced to the status of a déjà-vu. However, what makes his novella quite intriguing is his support of women's issues, a support that Al-Dadeesy perhaps rather exaggeratedly describes as "unconditional" to the extent of doubting whether the work has in fact been written by a man (Al- Dadeesy 2017, 6). This in its turn begs the question of whether Zeidan is to be classified as a feminist writer or is he to be relegated, albeit his highly acclaimed endorsement of women's rights, to the conventional position of a male wielding his time-worn phallic pen to add some colouring to a beautiful, time-honoured picture of ancient goddesses. The question indeed recalls Gilbert and Gubar's earlier argument that a pen is in some way a penis? (Gilbert 1996, 92) - an argument that literary history seems to have answered in the affirmative. In any case, myth does play a vital role in Zeidan's work whose time clock is set at a future date, precisely, June 30, 2020. Zeidan, also, like a true Aristotelian, decided to observe the three unities, making the work's events take place during the last day the heroine spends in Abdou's house before she leaves him for good .

As Ifrican maintains, "this limited time capsule condenses events," (Ifrican $2015,9)$ leaving almost half the novel to the mother's letters. Through flashback and interior monologues, we get to know what is ample enough to formulate an idea about Abdou and his wife, the two major characters in the novel, and about the mother and the grandfather as well. Interestingly, the protagonist's real name is never given. Instead, we are told of the nickname by which her husband likes to call her which is Nawa'im or "smoothy". This old-fashioned name that speaks of sensuality and of the soft texture of her skin is indicative enough of Abdou's 
mentality and his objectification of his wife who was his dream come true for the past seven years in which she had catered to his desires until the mother's letters started arriving to the mailbox, opening her eyes to her worth as a woman and to the baseness of her husband who does not measure up to her.

Abdou is clearly suffering from a deep sense of inferiority and low selfesteem. To himself, he is always "Abdou, the pathetic", (Zeidan 2008, 9) Abdou "the crushed one", (11) even Abdou "the demented"; (60) and yet his low esteem of women is patent to the point of vulgarity. He asks himself as he tries to figure out Nawaim's transformation:

Is she the same woman who would jump for joy if he took her out at night or if he accepted her invitation to a fancy restaurant? What happened to her?[...]. Nayel was right when he said: Disdain women so they may respect you. Refuse them so they may ask for you; and wait for the rice until it is stewed. Well, I've been patient and still she hasn't stewed [...]. Why doesn't this woman respect me? Does she think herself a wonder among women? She's pretty, I'll give her that, and tasty and smooth and playful at the right times. She's also a thoroughbred, but she is no rarity. She is like the rest of her kind, like all of them; all of them are the same. (Zeidan 2008, 49; translation mine $^{1}$ )

It is no wonder then that such a view of women had degraded the protagonist to anonymity. A name means an identity; whereas Nawa'im is a mere physical attribute good enough for love-making. After seven years of marriage, the protagonist realizes that the signifier chosen for her by her husband does not point to the right signified. The form does not seem to be absorbed by the concept. Signification is lacking, the association between the form and the concept is not gratifying or self-fulfilling. The heroine discovers that she has got the whole history of myth behind her. The appellation "Nawa'im" not only falls short of giving her her due, it is demeaning.

The protagonist's seven years of degraded objectification coalesces into the last night's rape scene when Abdou lures her to the "Eastern-room", as he liked to call it, and, while subjecting her to the influence of the aroma of hashish, rapes her. In one of her numerous interior monologues, prior to her rape, she addresses Abdou saying: 
Everything about me has become far away from you [...] I look at myself now and I don't see you reflected in my mirror. I only see you reflected on your feverish desire and your constant plan to turn me into a receptacle. Your delusions draw you to turn the receptacle of consciousness into a mere receptacle [...]. Why didn't you contain me all these years in your heart and soul? Do you have a heart and soul to start with? Or are you just a receptacle for the ants moving inside of you, gathering inside your testicles in the hope of finding a grove to be thrown inside it? Go find a grove for your ants and leave my paradise immaculate. The womb is a heaven and hell; and neither can contain the ants' manoeuvres. (78)

And yet, Abdou keeps pursuing Nawa'im like a vulture after a quarry, smooth talking to her and showing an ignorant man's sycophantic interest in Latin, music and French in the hope of finding a way to get through to her. When he lures her to the room of their past revelry where Nawa'im used to fulfill his dream of an oriental concubine, the hashish was bound to produce the desired effect as the heroine's mind was soaring to the transcendental realm of myth and sacred femininity. Taking her unawares, Abdou succeeds by sheer force to penetrate Nawa'im's long-barred fortress-a force that is tantamount to brutal masculinity not manhood. Zeidan describes the climactic point of the rape scene thus: "Inside her cave, his ejaculations were like viscid ants [...] for he was the superior, the stronger, and the more potent [...] he was relaxed; she was exiled. He was a fluttering eagle; she was a winding serpent" (90).

The hunter had ravished his quarry. Ironically, although the hash scheme was his friend's idea in the first place, the rape scene brings Abdou closer to Dalal, the university student cum prostitute, than to his friend Nayel. In other words, though Dalal may act as the heroine's double in more ways than one, she is a poignant crystallization of Abdou's anima cum doppelgänger. Abdou had certainly made use of Dalal's words on how a woman lures a man into chasing her, making him feel she is the quarry pursued by the hunter who will enjoy his feast, while all the time it was the woman who had set her eyes on him all along, sending signals, approaching then moving away so as to give him the pleasure of feeling that he is a skillful hunter, only to give him what she had planned on giving all along and for the duration that she saw fit (52).

Whether Dalal was echoing the thoughts of our nameless heroine when she married Abdou or echoing Abdou himself in trapping his wife before raping her, Dalal does call to mind the alluring Leilah just as Nawa'im resembles Leilah in 
so many ways. For instance, Leilah's 'serpentine' role in the temptation of Carter's Evelyn finds Edenic echoes in The Shadow of the Serpent which as seen in the way Abdou describes how he first met his wife. He recounts how he lost his bearings when he came close to her and how he was swept off his feet when she was almost two metres away from him (Zeidan 2008, 16-17) - a description that is reminiscent of the verses in the Quranic chapter "The Star" in which Prophet Muhammad's journey to the heavens and the holy encounter are metaphorically described.

In the same vein, Nawa'im and her foreign mother, likewise, conjure up Carter's Leilah and her godhead mother as their doubles, respectively; though instead of presiding as a deity, the mother in The Shadow of The Serpent is a scholar in ancient history, anthropology and the origin of religions. In point of fact, Nawa'im's mother is credited for introducing a theory to the understanding of myth. The mother tells her daughter in one of the letters that a myth is far greater than just a few lines summarizing it, even greater than the events it purports to recount. A myth, she says, is a form of address guy in a story. The manner in which it is told is in no way less important than the recounted story itself (Zeidan 2008, 135). She also adds that a myth always has several versions, each with a different perspective from the authorized one. Every mythical text, the mother posits, contains the consciousness of the generation that passes it on, a consciousness that is peculiar to that generation's history and geography. The version that has finally reached us is but one form of that consciousness that had formulated that myth throughout time and place or along its vertical and horizontal development (134-38). Myth, then, for Nawa'im's mother, occupies both space and time, unlike The Passion of New Eve where myth's ionic space was always embroiled in a battle with phallocentric time.

In Carter's novel, the Mother's battle was against phallocentricity, a battle that had made the Mother literalize her figure of speech into Beulah, the womblike spiral dug into the viscera of the earth. In Zeidan's work, however, the mother is exiled to some foreign land by the heroine's powerful grandfather, aka the Pasha. The Pasha, in post Nasser's Coup d' Etat of 1952, which ended monarchy and the Mohamed Ali dynasty, does not refer to some honorary title bestowed by the monarch. The Pasha, under Egypt's military regime, usually designates a high or even low-echelon police or military officer. And Nawa'im's grandfather belongs to the military category, a war veteran in his own right and a witness to the Defreswar gap in the 1973 War.

The Pasha is a symbol not only of authority but of male chauvinism. His eighty something years had only hardened him even more against the 
protagonist's mother. Still powerful enough, he was able to pull some strings to drive the girl's mother away after the death of his only son. In her letters, the mother tells Nawa'im how the military sees a danger in womanhood. The mother, for instance, tells her daughter in one of the letters that "[ $t]$ he military propensity as exemplified in your grandfather, the inveterate soldier, .... is an oppressive kind of propensity that sees in the spirit of womanhood a danger to man's authority" (162-63).

Indeed, if Abdou stands for the sheer animality of male instinct that insists on sensuous gratification at all cost, the grandfather stands for sheer power and authority, both of which are enough to always put Abdou in his right place, but not Nawa'im. Abdou can still remember how she ran about naked in her grandpa's house, using his own bed for her love-making while her grandfather was away burying his brother. Standing up against her grandfather, defending her own mother and rejecting his intercession for Abdou was the final blow to his male and military authority. The protagonist has finally come into her own; that is, a serpent, "hidden [but] recalcitrant" (13). The grandfather, though angry at his rebellious girl and still casting aspersions on her mother, can only withdraw like a veteran soldier certain of his defeat, leaving Abdou to work out his problem by himself.

The grandfather's lack of resistance leaves Abdou in the lurch so to speak. Being the sycophantic weakling that he is, Abdou was always capitalizing on the grandfather's authority and wary of crossing him. In that context and with his marriage already in its final throes, Abdou's rape or his base desperate act of bravado ends his marriage as it were, leaving him almost emasculated-a fate that Abdou seems to anticipate and dread. An hour after his raping of the heroine, Abdou wakes up shivering at the sound of the dawn's call for prayer:

At first he thought it was that same nightmare finally coming into effect-that same stupid dream that he always has at the end the night: she comes in naked, holding a thin scalpel. She bends quietly in his direction while he is unable to budge; then she cuts his testicles with her blade and feeds them to him. (92)

Evelyn's forced sex change looms as a haunting nightmare in The Shadow of The Serpent, even if this imagined castration appears merely as a psychological disrobing of manhood that is heightened by his getting kicked in the face by the protagonist who leaves him in the nude next to his clothes. The heroine then packs her bag preparing to leave while Abdou is left lying among her mother's 
torn letters that trace woman's history from the time of her apotheosis at the dawn of history down to desecrating her image by power hungry men.

Unlike Carter's novel where a sense of ending is imminent, the mother in The Shadow of the Serpent rejects the apocalyptic view of the world. The ending, if such a lack of closure may be deemed so, promises a reunion between mother and daughter. The signifier of the mythical schema or the old linguistic sign may finally be absorbed by the mythical signified to reach significance or meaning. Myth is the magic trope in this equation; it is both catalyst and incentive. The last thing the protagonist was reading before she was led, musing, to the Eastern Room were a few papers containing some chants and invocations that strongly resonate of the chants and incantations in Carter's novel:

I am the mother of all things

The mistress of the elements

The initiator of the universes....

I am the truth residing behind all gods and goddesses

Before me they gather in a single form and shape....

But my real name is Isis. (Zeidan 2008, 67)

When Nawa'im leaves Abdou, he is left with the mother's eye-opening letters. The protagonist's departure promises a re-birth. The grandfather's dictatorial authority had been shaken; Abdou's defeat is complete and the seven-year charade of a marriage is finally over. It is interesting how the mother's last letter in the last pages of the novel is devoted to a discussion of power and authority, especially in the 'heart of the old world'. Since men were the ones who rewrote myths, they glorified their sex while women got demeaned. Throughout the centuries, the protagonist's mother declares, it is rare to find a ruler who has been collectively chosen or has been worthy of that choice. The road to the throne, she continues, was always through armies, disputes, dethroning, coups, intrigue and cold-blooded murder. Armies, thus, became the protectors of thrones (167). The result, the mother adds, is a ruler who suffers from self-contempt, driven by his desire to hide that feeling and at the same time protect his sovereignty (Zeidan 2008, 168). Abdou, whose name is a derivation of slave, had been the embodiment of such male authority, aided by the grandfather's symbolic military power. Our nameless heroine was able to free herself from them both, refusing to be crushed or defaced by their marginalization, their demonization and their stereotyping of woman. In her namelessness, the protagonist hence becomes a representative of all women. The impending union with the mother calls to mind 
Evelyn's last invocation that concludes Carter's novel: "Ocean, ocean, mother of mysteries, bear me to the place of birth" (Carter 2009, 187).

In sum, this paper illustrates how myth has been employed to reinstate woman in her primordial position as goddess, sovereign and life source. History's embattled stance with regard to myth has never been resolved - assuming of course that history itself is not 'the mythical' falsification of events that always get to be written by the dominant or the victorious. Utilizing Roland Barthes's formulation of myth which hypothesizes the existence of a mythical schema which is linked to a linguistic one, the paper also highlights dualities, binaries, juxtapositions, and paradoxes, not with the aim of resolving time-worn tensions, but with the hope of being able to zoom in on the intricate relationship that ties men and women since time immemorial.

The scale, as the two works reveal, tips in favor of Woman, for whom myth functions as an intermediary to give the logos both presence and signification. Myth thus becomes the catalyst that makes form, or the signifier point to its concept or signified (amidst and despite any fluidity in meaning), filling it and conceptualizing what existed formerly as a sign in the linguistic schema. Myth, in a nutshell, seems to be the fitting trope or figure of speech that epitomizes the glory of being a woman, with all the mystery and symbolism that the word signifies from a (post)structuralist perspective and within a postmodernist context.

\section{Endnotes}

1. All translation from Youssef Zeidan's novel are mine unless stated otherwise.

\section{Works Cited}

Abrams, M. H. 1993. A Glossary of Literary Terms. $6^{\text {th }}$ ed. Orlando: Harcourt. Al-Dadeesy, Al Kabeer. 2017. 'Al-Mara'a Fi Mashrou' Youssef Zeidan AlRiwa ' $i$ ' [Woman in Youssef Zeidan's Literary Project]. El-Sada.Net, January 26. http://elsada.net/29253/

Barthes, Roland. Mythologies. 1957. Translated by Annette Lavers. New York: The Noonday Press.

Carroll, Rachel. 2011. "Violent Operations: Revisiting the Transgendered Body in Angela Carter's The Passion of New Eve." Women: A Cultural Review 22, no.2-3: 241-255. https: // doi. org/1010.80/ 09574042.2011.587246. 
Carter, Angela. 1978. "Polemical Preface: Pornography in the Service of Women." In The Sadeian Woman and the Ideology of Pornography, 3-26. New York: Pantheon Books.

Carter, Angela. 2009 The Passion of New Eve. London: Virago.

Frye, Northrop. 1957. Anatomy of Criticism: Four Essays. Princeton: Princeton University Press.

Gilbert, Sandra M. and Susan Gubar.1996. "The Mad Woman in the Attic: The Woman Writer and The Nineteenth-Century Literary Imagination." In Feminist Literary Theory: A Reader, edited by Mary Eagleton, 91-8. New Jersey: Blackwell Publishing.

Hayman, Ronald. 2003. Marquis de Sade: The Genius of Passion. London: Tauris Parke Paperbacks.

Ifrican, Hassan. 2015. "Riwayat Zil Al-Afa'a Li Youssef Zeidan: Fi Al-Rigou'ila Qadasit Al-Ontha" [Youssef Zeidan's Novel The Shadow of the Serpent: The Return to the Sanctity of Femininity.] Qabaqaosayn.com, July 26.

Morales, Salomé Sola.2013. "Myth and the Construction of Meaning in Mediated Culture." KOME-An International Journal of Pure Communication Inquiry 1, no.2: 33-43. Komejournal.com.

The Holy Qur'an. 1983. Translated by A. Yusuf Ali. Maryland: Amana Corp. Pérez-Gil, Maria Del Mar. 2007. "The Alchemy of the Self in Angela Carter's The Passion of New Eve." Studies in the Novel 39, no. 2: 216-234.

Plato. Republic. 1999. Translated by John Llewelyn Davies and David James Vaughan. Ware: Wordsworth Editions Ltd..

Zeidan, Youssef. 2008. Zil Al Afa' $a$ [The Shadow of the Serpent]. Cairo: Dar AlShorouk. 